\title{
Creating Democratic Civic Universities in a Post-COVID-19 World: The IAU and Global Collaboration
}

\author{
Ira Harkavy
}

This essay is organized around four questions, the answers to which should, in my judgment, be helpful in thinking about universities now and in a post-pandemic world. My goal is to contribute to discussions and actions that result in the creation of democratic civic universities.

\section{What Are the Purposes of the University?}

The Council of Europe identified four purposes for higher education: preparation for sustainable employment, preparing students for active citizenship, personal development, and creating a broad advanced knowledge base through stimulating research and innovation. The COVID-19 pandemic and its impacts have led me to see these purposes as part of a larger purpose of developing and maintaining good democratic communities and societies, characterised by participation, cooperation and a commitment to the public good. Specifically, this involves the education of students for democratic citizenship and the creation of knowledge to advance the human condition.

Education for citizenship is, for me, the most significant purpose of the university. Specifically, higher education must educate not only able, but also ethical, empathetic, engaged, effective democratic citizens of a democratic society. In 1947, as a 19-yearold freshman at Morehouse College, Martin Luther King, Jr. wrote an article for the campus newspaper on the "Purpose of Education" that powerfully captures this idea. "We must remember," he wrote, "that intelligence is not enough. Intelligence plus

\footnotetext{
I. Harkavy $(\bowtie)$

University of Pennsylvania, Philadelphia, PA, USA

e-mail: harkavy@upenn.edu 
character-that is the goal of true education. The complete education gives one not only power of concentration, but worthy objectives upon which to concentrate."

The other central purpose of universities is to develop the knowledge needed to change the world for the better. In 1899, while an instructor at the University of Pennsylvania's Wharton School, W.E.B. DuBois wrote The Philadelphia Negro about conditions in the Seventh Ward, the city's oldest African American community. At the conclusion of chapter one, he described the purposes of his ground-breaking research as "serv[ing] as the scientific basis of further study, and of practical reform." That same year, in a paper delivered to the American Academy of Political and Social Science, Jane Addams, the activist, feminist founder of Hull House settlement in Chicago's poverty-stricken immigrant 19th ward neighbourhood, claimed that it was essential to "attempt to test the value of human knowledge by action" and "to apply knowledge to life."

My claim about the democratic purpose of higher education is derived in part from the history of colleges and universities in the United States. Every colonial college, except for the University of Pennsylvania, was founded largely to educate ministers and religiously orthodox men capable of creating good communities built on religious denominational principles. Benjamin Franklin, on the other hand, founded Penn (my home institution) as a secular college to educate students in a variety of fields. In 1749, envisioning the institution that would become the University of Pennsylvania, he wrote of developing in students "an Inclination join'd with an Ability to serve Mankind, one's Country, Friends and Family; which Ability . . . should indeed be the great Aim and End of all Learning."

Franklin's call to service echoed in the founding documents of hundreds of private colleges established after the American Revolution, as well as in the speeches of many college presidents. As the American research university evolved in the late 19th century, strengthening democracy at the expense of old social hierarchies served as increasingly the core mission of higher education in general.

Given the development of "illiberal democracy," claims of "fake news" and "alternative facts," and attacks on science and knowledge itself, universities have an increased and pressing responsibility to contribute to both the education of informed democratic citizens and the advancement of knowledge for the continuous betterment of the human condition. That pressing responsibility has become even more pressing with COVID-19, and claims that authoritarian systems are better able to deal with emergencies, along with a failure to acknowledge that authoritarian leaders have denied inconvenient truths that helped COVID-19 become a pandemic, producing a horrific toll in human life. 


\section{Are Universities in a Position to Make Sustained, Significant Contributions to Democracy?}

Higher education institutions, particularly research universities, are among the preeminent institutions in societies throughout the world, functioning as the primary engine of growth for knowledge-based global economies. Universities are sources of new ideas and discoveries, including technological advances; cultural and artistic centres; and anchor institutions that serve as catalysts and hubs for local and regional development. Most importantly, they teach the teachers, and the teachers' teachers, across all subjects, thereby helping to shape the entire schooling and educational systems at all levels, which shape the nature of society itself. As the great philosopher and educator John Dewey powerfully argued, a democratic society requires democratic education and schooling.

Certainly, higher education institutions are and will be negatively impacted by COVID-19. Many will struggle to survive, and many others could well close. Higher education as a sector, however, is and will remain influential in the years ahead. Among other things, colleges and universities possess significant resources, particularly the human resource of bright, able, idealistic students, faculty, and non-academic staff.

During the COVID crisis, higher education institutions, particularly academic medical centres, have in many ways performed admirably providing desperately needed health care and research; helping assure the safety of their students, faculty, and staff; supporting local businesses; donating medical equipment; teaching their students; and engaging with their communities remotely. There has been extraordinary, perhaps unprecedented, levels of collaboration and sharing of intelligence in a globally connected race to develop vaccines.

But this civic spiritedness, this social solidarity, is not a defining characteristic of higher education. The democratic civic university actively engaged with the life and problems of its community, and society has not been the primary model of higher education.

The International Association of Universities (IAU) has been a global leader supporting and advocating for academic engagement and genuinely engaged colleges and universities. Positive steps have been taken over the past decades in this direction. Service-learning, engaged scholarship, community-based participatory research, volunteer projects, and community economic development initiatives are some of the approaches that have been developed to create mutually beneficial partnerships designed to make a positive difference in the community and on the campus. 


\section{What Are the Obstacles to Creating Democratic Civic Universities?}

Significant obstacles have impeded the development of truly engaged, democratic civic universities, however. These impediments include commercialism and commodification, misplaced nostalgia for traditional, elitist, 'ivory tower' liberal arts education, and intellectual and institutional fragmentation.

The neoliberal entrepreneurial university is a model that has gained increasing currency and power throughout the world, contributing to increasingly savage inequalities and a diminished sense of public purpose. Education for profit, not virtue, students as consumers, not producers of knowledge, academics as individual superstars, not members of a community of scholars - all of these developments reflect the commercialization of higher education, which contributes to an overemphasis on institutional competition for wealth and status and has a devastating impact on the values and ambitions of students. When institutions openly pursue commercialization, their behaviour legitimizes and reinforces the pursuit of economic self-interest by students and amplifies the widespread sense that they are in college or university exclusively to gain career-related skills and credentials. Student idealism and civic engagement are strongly diminished when students see their universities abandon academic values and scholarly pursuits to function as competitive, profit-making corporations. Commercialism and the development of the neoliberal university foster an environment in which higher education is seen as a private benefit, not a public good.

Partly in response to galloping commercialism, some make a case for a return to traditional liberal arts education - an essentialist approach with roots in Plato's anti-democratic, elitist theory of education. What is needed instead is, to quote Carol Geary Schneider, "a new liberal art" involving "integrative learning - focused around big problems and new connections between the academy and society." The concept of a new liberal art resonates with John Dewey's rejection of abstract contemplation and his call for an engaged, problem-solving approach to scholarship and learning. In Reconstruction in Philosophy, he wrote: "The social philosopher, dwelling in the region of his concepts, 'solves' problems by showing the relationship of ideas, instead of helping men solve problems in the concrete by supplying them hypotheses to be used and tested in projects of reform."

"Communities have problems, universities have departments," stated a report published by the Organization for Economic Cooperation and Development titled The University and the Community. Beyond being a criticism of universities, that statement neatly indicates another major reason why universities have not contributed to communities as they should. Quite simply, their unintegrated, fragmented, internally conflictual structure and organization impede understanding and developing solutions to highly complex human and societal problems.

Colleges and universities need to significantly decrease the fragmentation of disciplines, overspecialization, and division between and among the arts and sciences and the professions since these departmental and disciplinary divisions have increased 
the isolation of higher education from society itself. Compounding this problem is what might be called the 'disciplinary fallacy' afflicting US universities - namely, the misconception that faculty members are duty-bound to serve only the scholastic interests and preoccupations of their disciplines and have neither the responsibility nor the capacity to help their universities keep their longstanding promise to prepare undergraduates for lives of moral and civic responsibility.

\section{What Is the Role of Global Collaboration in Reducing Obstacles to Creating Democratic Civic Universities?}

Many things need to be done, and done with urgency, to reduce the negative effects of commercialism and commodification, ivory tower nostalgia, and intellectual and institutional fragmentation. Space considerations would make it impossible to enumerate them here. Among the actions needed, however, is to create a global movement of individuals and organizations, including colleges and universities, for change. Simply put, promoting increased cooperation among higher education institutions all over the world to learn from and work with each other is a necessity. That is precisely what the IAU does, serving as a truly global association of higher education institutions and organizations from around the world advocating for social responsibility and higher education and research in the public interest.

Importantly, the IAU is also a core member (along with the Council of Europe, Organization of American States, and the International Consortium for Higher Education, Civic Responsibility and Democracy) of a global cooperation to advance the democratic role of higher education. Let me provide a bit of background.

The International Consortium for Higher Education, Civic Responsibility and Democracy (IC) was formed in 1999 to work in cooperation with the Council of Europe (CoE). The purpose of the IC (which I chair) is to advance the contributions of institutions of higher education to democratic development on campus, as well as in local communities and the wider society. The IC comprises the United States (represented by a Steering Committee from the American Association of State Colleges and Universities, American Council on Education, Anchor Institutions Task Force, Association of American Colleges and Universities, Campus Compact, Democracy Commitment, and NASPA-Student Affairs Professionals in Higher Education); Australia (represented by Engagement Australia); the United Kingdom (represented by the National Co-ordinating Centre for Public Engagement); Ireland (represented by Campus Engage Ireland); South Africa (represented by Universities South Africa); and the Magna Charta Observatory based in Italy.

The CoE, established in 1949, defends human rights, democracy and the rule of law, develops continent-wide agreements to standardize member countries' social and legal practices, and promotes awareness of a European identity across cultures based on shared values. The IC, for example, works in collaboration with the CoE, comprising 47 member countries, and its Steering Committee for Educational Policy 
and Practice. The Steering Committee includes an additional three countries that are also signatories of the European Cultural Convention. This treaty provides the framework for the CoE's work in education policy and practice.

In Spring 2018, the Organization of American States (OAS) joined the cooperation between the IC and CoE. The OAS was established in 1948 "in order to achieve among its member states - as stipulated in Article 1 of the Charter -'an order of peace and justice, to promote their solidarity, to strengthen their collaboration, and to defend their sovereignty, their territorial integrity, and their independence.' Today, the OAS brings together all 35 independent states of the Americas and constitutes the main political, juridical, and social governmental forum in the Hemisphere." The organization uses a four-pronged approach based on its main pillars of democracy, human rights, security and development.

In Autumn 2019, the International Association of Universities (IAU) joined the $\mathrm{CoE} / \mathrm{IC} / \mathrm{OAS}$ cooperation. Created under the auspices of UNESCO in 1950, the IAU, as readers know, is a membership-based organization serving the global higher education community and currently represents more than 640 institutions, organizations and affiliates across 120 countries. The IAU "acts as the global voice of higher education to UNESCO and other international higher education organizations, and provides a global forum for leaders of institutions and associations... The Association advocates for policies and practices that respect diverse perspectives and promote social responsibility."

The IC/CoE/OAS/IAU cooperation undertakes cross-national research projects, joint meetings and the sharing of best practices as part of its efforts to advance higher education's contribution to building democratic societies. The cooperation has hosted six global forums, and the CoE has published monographs on the conference themes, including Higher Education and Democratic Culture: Citizenship, Human Rights, and Civic Responsibility (2008), Higher Education for Modern Societies: Competencies and Values (2010), Reimagining Democratic Societies: A New Era of Personal and Social Responsibility (2013), Higher Education for Democratic Innovation (2016), Higher Education for Diversity, Social Inclusion, and Community: A Democratic Imperative (2018), and Academic Freedom, Institutional Autonomy, and the Future of Democracy (2020). Additional partners were involved in planning the conferences, among them being the International Association of Universities (well before it became a formal member), the European Wergeland Centre, the European Students' Union, the University of Oslo, Queen's University-Belfast, the Australia Catholic University and LUMSA University.

The IAU and the global cooperation of which it is a part have, in my opinion, their roots in the Enlightenment idea powerfully expressed by Francis Bacon at the turn of the 17th century that "knowledge is power" for "the relief of man's estate." To realize his goal of advancing knowledge "for the relief of man's estate," Bacon also called for a "closer connection and relationship between all the different universities of Europe."

Now, of course, connections and relationships must extend well beyond Europe. Collaboration for research, learning, and engagement is necessary to increasingly realize the progressive, continuous betterment of the human condition and create 
democratic civic universities dedicated to producing knowledge and educating ethical, empathetic students for just and sustainable democratic societies. IAU has been, and will surely continue to be, a catalyst and leader of that collaboration.

Ira Harkavy is Associate Vice President and Founding Director of the Barbara and Edward Netter Center for Community Partnerships, University of Pennsylvania. He also chairs the International Consortium for Higher Education, Civic Responsibility and Democracy and the Anchor Institutions Task Force. His recent books include Knowledge for Social Change: Bacon, Dewey, and the Revolutionary Transformation of Research Universities in the Twenty-First Century (2017) and The Local Mission of Higher Education: Principles and Practice (2019, co-edited with Sjur Bergan and Ronaldo Munck).

Open Access This chapter is licensed under the terms of the Creative Commons Attribution 4.0 International License (http://creativecommons.org/licenses/by/4.0/), which permits use, sharing, adaptation, distribution and reproduction in any medium or format, as long as you give appropriate credit to the original author(s) and the source, provide a link to the Creative Commons license and indicate if changes were made.

The images or other third party material in this chapter are included in the chapter's Creative Commons license, unless indicated otherwise in a credit line to the material. If material is not included in the chapter's Creative Commons license and your intended use is not permitted by statutory regulation or exceeds the permitted use, you will need to obtain permission directly from the copyright holder. 